\title{
Evaluasi Efektivitas Program Kang Pisman di Kelurahan Sukaluyu dan Faktor yang Mempengaruhinya
}

\author{
Poppy Yuanita ${ }^{1}$, Yeremias T. Keban ${ }^{2}$ \\ ${ }^{1}$ Mahasiswa Magister Perencanaan Wilayah dan Kota UGM, Yogyakarta, Indonesia \\ ${ }^{2}$ Dosen Magister Perencanaan Wilayah dan Kota UGM, Yogyakarta, Indonesia \\ Email: poppyyuanita@mail.ugm.ac.id
}

Received 19 Juni 2020 | Revised 15 Juli 2020 | Accepted 17 Juli 2020

\begin{abstract}
ABSTRAK
Pengelolaan sampah telah menjadi salah satu permasalahan yang jamak terjadi di perkotaan. Produksi sampah meningkat seiring dengan pertambahan penduduk dan jumlah konsumsi serta gaya hidup masyarakat, namun tidak diimbangi dengan pengelolaan sampah yang ramah lingkungan dan berkelanjutan. Untuk itu, diperlukan upaya untuk mulai mengurangi, memisahkan, dan memanfaatkan sampah. Program Kang Pisman adalah konsep yang diperkenalkan oleh Pemerintah Kota Bandung untuk mengatasi masalah tersebut.Tujuan dari penelitian ini adalah mengevaluasi efektivitas Program Kang Pisman dan mengetahui faktor yang memepengaruhinya. Evaluasi efektivitas perlu dilakukan untuk mengetahui apakah hasil dari program tersebut sudah sesuai dengan tujuan awal perencanaan. Metode dalam penelitian ini adalah deskriptif kuantitatif dengan menggunakan instrumen pengumpulan data berupa kuesioner terhadap 98 rumah yang menjadi sampel penelitian. Efektivitas Program Kang Pisman penting untuk diteliti begitu juga faktor yang berpengaruh terhadap program tersebut agar dapat digunakan sebagai bahan evaluasi program dan menjadi masukan dalam membuat kebijakan lebih lanjut tentang pelaksanaan program. Hasil skoring variabel efektivitas menunjukkan bahwa Program Kang Pisman ada pada tingkatan cukup efektif. Untuk mengetahui faktor yang mempengaruhi efektivitas program, dilakukan analisis regresi linear berganda dengan enam variabel bebas, yaitu komitmen pemerintah, kemudahan menjalankan program, kinerja petugas pelaksana, ketersediaan sarana dan prasarana, peran Lembaga Swadaya Masyarakat (LSM) dan persepsi masyarakat. Faktoryang berpengaruh signifikan terhadap efektivitas adalah persepsi masyarakat dan kemudahan dalam menjalankan program.
\end{abstract}

Kata kunci: evaluasi efektivitas, kang pisman, pengelolaan sampah.

\begin{abstract}
Solid waste management is one of the global problems faced by urban areas. Waste generation increased according to population growth and followed by consumption and lifestyle, however not balanced with the management of waste that is environmentally friendly and sustainable. We need to reduce, sort, and reuse the waste. The Kang Pisman Program is a concept introduced by the Bandung City Government to overcome this problem. The objectives of this research are to evaluate the effectiveness of the program and its influential driving factors. Evaluation of effectiveness needs to be held to find out wheater the results of the program are following the original purpose. This research uses a quantitative descriptive method with a questionnaire instrument to interview 98 houses as a sampling. The effectiveness of the Kang Pisman Program is essential to evaluate as well as the factors that influence the program so that it can be used as a program evaluation material and be input in making further policy regarding program implementation. The scoring result shows that Kang Pisman Program is at quite effective level. To find out the factors that influence the effectiveness of the program, multiple linear regression analysis was carried out with six independent variabels, namely goverment commitment, ease of running the program,
\end{abstract}


the staff performance, infrastructure, the role of NGOs and community perceptions. Factors that have a significant influence on effectiveness are community perception and ease in running the program.

Keywords: effectiveness evaluation, kang pisman, waste management.

\section{PENDAHULUAN}

Permasalahan lingkungan yang dihadapi wilayah perkotaan salah satunya adalah persoalan sampah. Produksi sampah meningkat seiring dengan pertambahan penduduk dan jumlah konsumsi serta gaya hidup masyarakat. Hal ini tidak diimbangi dengan pengelolaan sampah yang ramah lingkungan dan berkelanjutan. Kebanyakan negara berkembang menghadapi masalah kurangnya fasilitas daur ulang dan tingkat pemilahan sampah yang rendah [1]. Rata-rata produksi sampah di Kota Bandung setiap hari adalah 1.600 Ton. Sebagian besar sampah di Kota Bandung bersumber dari permukiman dengan presentase mencapai $65,6 \%$ dari total rata-rata produksi sampah per harinya. Sisanya berasal dari pasar $18,8 \%$, perkantoran $5,5 \%$, daerah komersil $6 \%$, fasilitas publik $2,8 \%$ dan lainya $1,3 \%$ [2].

Pengelolaan sampah saat ini masih dilakukan dengan pola kumpul - angkut - buang. Pengurangan sampah pola 3R (Reduce, Reuse, Recycle) hanya mencapai 14,2\% sedangkan sebanyak 73,7\% diangkut ke Tempat Pengolahan dan Pemrosesan Akhir Sampah (TPPAS) regional Sarimukti di Kabupaten Bandung yang jaraknya $>40 \mathrm{~km}$ dari Kota Bandung dan sisanya adalah sampah yang belum tertangani tercecer di sudut kota atau hanyut ke sungai. TPPAS tersebut diperkirakan mencapai daya tampung maksimal pada tahun 2023. Total sampah yang bersumber pada permukiman sebagian besar adalah sampah organik sekitar $63 \%$, sampah yang bisa di daur ulang sebanyak $23 \%$ sedangkan sisanya sebanyak $14 \%$ adalah sampah residu [2]. Artinya, Kota Bandung potensial untuk dapat mengurangi jumlah sampah rumah tangga yang di angkut ke TPA (Tempat Pemrosesan Akhir) dengan melakukan pemilahan sampah sejak dari sumber dan mengolah sampah organiknya. Membuang sampah ke TPA hanyalah memindahkan sampah tersebut dari lokasi rumah tangga ke TPA seperti memindah masalah dari satu tempat ke tempat lainnya. Pengelolaan sampah saat ini hanya memperhatikan TPA (end of pipe) tanpa memperhitungkan proses yang dapat dilakukan di sumber dengan menerapkan 3R. Hal ini menyebabkan beban TPA menjadi berat dan umur penggunaannya semakin pendek [3]. Pengelolaan sampah meliputi pengurangan dan penanganan sampah (pemilahan, pengumpulan, pengolahan, pengangkutan, dan pemrosesan akhir) harus dilakukan sistematis, menyeluruh dan berkesinambungan, akan tetapi masih banyak masyarakat yang belum mengerti cara yang tepat dalam menangani sampah yang mereka hasilkan sendiri. Hal inilah yang membuat permasalahan pengelolaan sampah menjadi masalah yang serius untuk ditangani.

Pemerintah Kota Bandung memperkenalkan konsep pengelolaan sampah 3R dalam bentuk yang mudah diterima masyarakat lokal karena memiliki unsur kesundaan dan agar lebih akrab di lingkungan masyarakat dengan membuat program Kang Pisman (kurangi, pisahkan, dan manfaatkan). Kang Pisman diharapkan menjadi gerakan kolaborasi antara pemerintah, warga, swasta dan pihak lainnya dalam membangun peradaban baru pengelolaan sampah yang lebih maju. Tujuan dari program Kang Pisman ini mengarah pada pengelolaan sampah dengan konsep zero waste. Prinsip nol sampah merupakan konsep pengelolaan sampah yang didasarkan pada kegiatan minimalisasi, penggunaan kembali dan daur ulang. Zero waste bukan berarti tidak menghasilkan sampah sama sekali, namun menekankan pada upaya pengurangan hingga nol sampah yang diangkut ke TPA. Penanganan sampah ini sejalan dengan target Sustainable Development Goals (SDGs) bahwa pada tahun 2030 setiap negara secara substansial mengurangi produksi limbah melalui pencegahan, pengurangan, daur ulang, dan penggunaan kembali, untuk menjamin pola produksi dan konsumsi yang berkelanjutan yaitu tujuan 12.5 [4].

Tujuan dari penelitian ini adalah mengevaluasi efektivitas Program Kang Pisman dan mengetahui faktor yang memepengaruhinya. Penilaian efektivitas tidak hanya menghasilkan tingkat efektivitas 
program tersebut, tapi lebih dalam dapat melihat indikasi kelemahan dan kekuatan di masing-masing aspek program. Dengan dilakukan evaluasi efektivitas, dapat diketahui apa yang perlu diperbaiki baik di sisi konsep, sumber daya, proses maupun capaian yang diinginkan, supaya kegiatan dapat berjalan dengan lebih baik dan memberikan lebih banyak manfaat positif. Efektivitas Program Kang Pisman penting untuk diteliti begitu juga faktor yang berpengaruh terhadap program tersebut agar dapat digunakan sebagai bahan evaluasi program dan menjadi masukan dalam membuat kebijakan lebih lanjut tentang pelaksanaan program. Saat ini Program Kang Pisman baru diterapkan pada 8 kelurahan dari total 151 kelurahan di Kota Bandung sehingga didapatkan gambaran apakah program tersebut efektif dalam mengurangi masalah sampah untuk dapat diterapkan di kelurahan lain. Sedangkan mengetahui faktor apa yang berpengaruh signifikan akan memberikan gambaran untuk program ke depan, bagian mana dari program yang perlu untuk lebih dikuatkan.

\section{TINJAUAN PUSTAKA}

Sampah menjadi persoalan rumit terutama dalam masyarakat yang kurang memiliki kepekaan terhadap lingkungan. Sampah menjadi polemik tersendiri dalam problematika kultural. Dalam perencanaan kota yang berkelanjutan, manajemen persampahan adalah salah satu aspek yang paling menantang karena budaya masyarakat industrial saat ini yang mengkonsumsi banyak produk over packaging, sekali pakai, food waste dan e-waste [5]. Pengelolaan sampah menjadi tantangan yang berat bagi negara sedang berkembang [6].

Penanganan sampah seharusnya fokus pada peningkatan kapasitas manusia, tidak sekedar menambah peralatan pegumpulan sampah atau membuat landfill [7]. Memendam sampah (landfill) dan membakar sampah (incineration dan gasification) bukan solusi yang mendukung keberlanjutan pengelolaan sampah, berbeda dengan pengomposan, penggunaan kembali, dan daur ulang [8]. Pengelolaan sampah tidak dapat diatasi hanya dengan teknologi, tetapi dengan organisasi, pendidikan dan juga desain industri yang lebih baik.

Evaluasi program adalah suatu rangkaian kegiatan yang dilakukan untuk melihat tingkat keberhasilan program. Evaluasi program juga dapat diartikan dengan pengumpulan informasi secara sistematis mengenai karakteristik dan dampak dari program untuk membuat keputusan mengenai program, kefektifan pelaksanaan program dan keberlanjutan program [9]. Pertanyaan yang seringkali diajukan dalam penelitian evaluasi adalah apakah program telah sukses mencapai tujuan, apakah ada cara yang lebih baik dalam mencapai tujuan dan apakah benar-benar program itu sendiri yang mempengaruhi ketercapaian tujuan atau faktor lain dari luar program [10].

Pengertian lain efektivitas program adalah tingkatan dimana suatu program menghasilkan outcome yang dapat memberikan kepuasan kepada masyarakat [11]. Sehingga secara sederhana efektivitas dipahami sebagai tingkat atau derajat pencapaian tujuan dan sasaran, baik dalam organisasi, program, dan dengan persentase hasil yang maksimal. Analisis efektivitas juga tepat digunakan pada hal-hal yang intangible karena untuk mengukur suatu dampak sulit dinyatakan dalam bentuk nilai uang dan satuan ukuran yang umum.

Ada banyak faktor atau variabel yang mempengaruhi keberhasilan dari implementasi program, baik bersifat eksternal, internal, individual, kelompok maupun institusi. Beberapa faktor yang dapat mempengaruhi kinerja dan dampak suatu program antara lain: hubungan antar organisasi, sumber daya program, karakteristik pelaksana program dan faktor lingkungan [12]. 


\section{METODOLOGI}

\subsection{Pengukuran Efektivitas}

Pendekatan yang digunakan dalam penelitian ini adalah deduktif dengan prosedur analisa deskriptif kuantitatif. Pendekatan deduktif dilakukan dengan pendalaman beberapa teori yang menghasilkan kriteria variabel untuk melihat dan menguji kenyataan yang terjadi di lapangan. Pada prosedur analisis deskriptif, peneliti menyajikan data-data penelitian dan menganalisis temuan-temuan yang ada serta memberikan tinjauan kritis. Pendekatan kuantitatif dalam hal ini sesuai untuk digunakan dalam penelitian efektivitas karena dapat menghasilkan generalisasi dari temuan penelitian yang dapat digunakan untuk memprediksi situasi serupa pada lokasi lain.

Tahapan yang dilakukan untuk memperoleh data pada penelitian ini diawali dengan kajian pustaka sebagai dasar untuk menentukan variabel dalam penelitian ini. Dari variabel yang sudah diperoleh selanjutnya dapat digunakan untuk menentukan data apa yang diperlukan sebagai bahan untuk memperoleh data primer.

Populasi dalam penelitian ini meliputi seluruh rumah di Kelurahan Sukaluyu, Kecamatan Cibeunying Kaler, Kota Bandung. Kelurahan Sukaluyu merupakan salah satu dari delapan kelurahan yang ditetapkan sebagai percontohan Kawasan Bebas Sampah (KBS) di Kota Bandung dan sering mendapat kunjungan dari berbagai elemen masyarakat baik dalam maupun luar negeri yang ingin mempelajari pengelolaan sampah berkelanjutan. Menurut data awal yang didapatkan dari pihak kelurahan, terdapat total sebanyak 4.162 rumah di kelurahan ini. Mempertimbangkan alokasi waktu, dana dan juga tenaga maka dilakukan pengambilan sampel dari populasi. Sesuai rumus Slovin diperoleh jumlah rumah yang menjadi sampel dalam penelitian ini sebanyak 98, dengan tingkat kesalahan penetapan sampel $10 \%$ [13]. Jumlah tersebut dibagi untuk setiap RW secara Proportionate Stratified Random Sampling (pengambilan sampel acak terstratifikasi secara proporsional). Penggunaan RW sebagai strata dalam pengambilan sampel dilakukan karena pengelolaan sampah rumah tangga dikoordinasikan oleh RW setempat, sehingga dimungkinkan terdapat perbedaan pada setiap RW. Setelah didapatkan jumlah sampel yang harus diambil di tiap RW, kemudian digunakan teknik pengambilan sampel secara Simple Random Sampling. Hal ini memberikan peluang yang sama bagi setiap anggota sub populasi untuk dipilih menjadi anggota sampel.

Untuk menentukan efektifitas Program Kang Pisman dilakukan skoring terhadap jawaban responden. Masing-masing variabel mempunyai kriteria jawaban yang dapat dipilih oleh responden. Tabel 1 menyajikan variabel dan kriteria yang digunakan dalam evaluasi efektivitas dalam penelitian ini dan skor dari masing-masing kategori. 
Tabel 1. Variabel efektivitas Program Kang Pisman

\begin{tabular}{|c|c|c|}
\hline No & Variabel & Kriteria \\
\hline 1. & $\begin{array}{l}\text { Motivasi mengikuti } \\
\text { program }\end{array}$ & $\begin{array}{l}\text { Termotivasi } \rightarrow \text { Efektif }(4) \\
\text { Cukup Termotivasi } \rightarrow \text { Cukup Efektif (3) } \\
\text { Kurang Termotivasi } \rightarrow \text { Kurang Efektif }(2) \\
\text { Tidak Termotivasi } \rightarrow \text { Tidak Efektif }(1)\end{array}$ \\
\hline 2. & $\begin{array}{l}\text { Kehadiran dalam } \\
\text { sosialisasi program }\end{array}$ & $\begin{array}{l}\text { Hadir Sendiri } \rightarrow \text { Efektif }(3) \\
\text { Salah satu ART } \rightarrow \text { Kurang Efektif }(2) \\
\text { Tidak Hadir } \rightarrow \text { Tidak Efektif }(1)\end{array}$ \\
\hline 3. & $\begin{array}{l}\text { Pengetahuan tentang } \\
\text { program }\end{array}$ & $\begin{array}{l}\text { Menjawab benar ketiganya } \rightarrow \text { Efektif }(4) \\
\text { Menjawab benar dua } \rightarrow \text { Cukup Efektif ( } 3 \text { ) } \\
\text { Menjawab benar satu } \rightarrow \text { Kurang Efektif (2) } \\
\text { Menjawab salah semua } \rightarrow \text { Tidak Efektif (1) }\end{array}$ \\
\hline 4. & $\begin{array}{l}\text { Pengurangan } \\
\text { penggunaan plastik dan } \\
\text { barang sekali pakai }\end{array}$ & \multirow{3}{*}{$\begin{array}{l}\text { Sering } \rightarrow \text { Efektif }(4) \\
\text { Cukup Sering } \rightarrow \text { Cukup Efektif (3) } \\
\text { Jarang } \rightarrow \text { Kurang Efektif (2) } \\
\text { Tidak Pernah } \rightarrow \text { Tidak Efektif (1) }\end{array}$} \\
\hline 5. & $\begin{array}{l}\text { Pemilaan sampah sejak } \\
\text { dari sumber }\end{array}$ & \\
\hline 6. & $\begin{array}{l}\text { Memanfaatkan kembali } \\
\text { sampah yang masih } \\
\text { bisa digunakan }\end{array}$ & \\
\hline 7. & $\begin{array}{l}\text { Pengurangan jumlah } \\
\text { sampah yang dibuang } \\
\text { ke TPA }\end{array}$ & $\begin{array}{l}\text { Berkurang Banyak } \rightarrow \text { Efektif (4) } \\
\text { Berkurang Sedikit } \rightarrow \text { Cukup Efektif (3) } \\
\text { Tetap } \rightarrow \text { Kurang Efektif }(2) \\
\text { Bertambah } \rightarrow \text { Tidak Efektif }(1)\end{array}$ \\
\hline
\end{tabular}

Sesuai dengan tujuan penelitian, maka analisis data dilakukan dengan memberikan kategori terhadap jawaban responden. Kategori jawaban responden diberi nilai atau skor di masing-masing pertanyaan. Skor paling tinggi adalah 4 dan skor paling rendah adalah 1, kecuali pada pertanyan kehadiran dalam sosialisasi program, skor tertinggi adalah 3. Dengan jumlah responden sebanyak 98, maka nilai maksimal yang dapat dicapai adalah $(6 \times 4 \times 98)+(1 \times 3 \times 98)=2.646$ dan nilai minimal adalah $7 \times 1$ x $98=686$. Setelah itu didapatkan rentang (range) skor tingkat efektivitas program dengan perhitungan sebagai berikut:

$$
\begin{aligned}
\text { Interval } & =\frac{\text { skor maksimal }- \text { skor minimal }}{\text { banyaknya kategori }} \\
& =\frac{2.646-686}{4}
\end{aligned}
$$

Nilai maksimal yang dapat diperoleh adalah 2.646 dan nilai minimal adalah 686, sedangkan rentang antar kategori didapatkan nilai 490, maka diperoleh klasifikasi efektivitas program Kang Pisman sebagai berikut: 
Tabel 2. Klasifikasi efektivitas berdasarkan skor total

\begin{tabular}{cc}
\hline Skor & Klasifikasi Efektivitas \\
\hline $686-1.176$ & Tidak Efektif \\
\hline $1.177-1.667$ & Kurang Efektif \\
\hline $1.668-2.158$ & Cukup Efektif \\
\hline $2.159-2.649$ & Efektif \\
\hline
\end{tabular}

\subsection{Analisis Faktor yang Mempengaruhi Efektivitas}

Faktor-faktor yang memepengaruhi efektivitas Program Kang Pisman dapat diketahui dari hasil uji statistik dengan regresi linear berganda. Uji ini dilakukan variabel bebas lebih dari satu. Sebelum dilakukan regresi, data penelitian harus memenuhi asumsi normalitas, tidak terjadi heteroskedastisitas, dan tidak multikolinearitas. Selain uji asumsi tersebut, syarat lain yang harus dipenuhi adalah data berjenis interval/rasio. Data dalam penelitian ini adalah ordinal dengan menggunakan skala likert 4 tingkat, maka perlu dilakukan konversi agar data menjadi skala interval dengan menggunakan MSI (Method of Successive Interval).

Variabel terikat $(\mathrm{Y})$ yang digunakan adalah Efektivitas Program Kang Pisman sedangkan variabel bebas $(\mathrm{X})$ sebanyak 6 variabel, yaitu:

$\mathrm{X}_{1}=$ komitmen pemerintah terhadap program

$\mathrm{X}_{2}=$ kemudahan dalam menjalankan program

$\mathrm{X}_{3}=$ kinerja petugas pelaksana program

$\mathrm{X}_{4}=$ ketersediaan sarana dan prasarana

$\mathrm{X}_{5}=$ peran LSM

$\mathrm{X}_{6}=$ persepsi

Persamaan yang dapat digunakan sebagai prediksi adalah sebagai berikut:

$Y=c+b_{1} \cdot X_{1}+b_{2} \cdot X_{2}+b_{3} \cdot X_{3}+b_{4} \cdot X_{4}+b_{5} \cdot X_{5}+b_{6} \cdot X_{6}$

Dimana:

$\mathrm{c} \quad=$ konstanta

$\mathrm{b}_{1-6} \quad=$ koefisien regresi

$\mathrm{Y} \quad=$ variabel terikat

$\mathrm{X}_{1-6} \quad=$ variabel bebas

$\mathrm{e} \quad=$ standard error

Pengukuran variabel bebas dilakukan dengan mengajukan beberapa butir pertanyaan dalam kuesioner terkait dengan substansi variabel tersebut dan responden tinggal memilih tingkat jawaban yang sesuai dengan tingkat kepuasan mereka. Tabel 3 dan 4 menjelaskan variabel dan kriteria jawaban dari masing-masing variabel bebas.

Tabel 3. Penilaian variabel bebas

\begin{tabular}{lll}
\hline No & \multicolumn{1}{c}{ Variabel } & \multicolumn{1}{c}{ Kriteria } \\
\hline 1 & Komitmen terhadap program & Puas $\rightarrow 4$ \\
& Kemudahan dalam menjalankan program & Cukup Puas $\rightarrow 3$ \\
\cline { 1 - 2 } & Kinerja petugas pelaksanan prgoram & Kurang Puas $\rightarrow 2$ \\
Tidak Puas $\rightarrow 1$ \\
\hline 4 & Ketersediaan sarana dan prasarana & \\
\hline 5 & Peran LSM & \\
\hline
\end{tabular}


Khusus variabel persepsi dihasilkan dari penjumlahan skor beberapa pertanyaan berikut ini:

Tabel 4. Komposisi pertanyaan penyusun persepsi

\begin{tabular}{|c|c|c|}
\hline No & Variabel & Kriteria \\
\hline 1 & Sampah rumah tangga perlu dikelola setiap hari & \multirow{9}{*}{$\begin{array}{l}\text { Setuju } \rightarrow 4 \\
\text { Cukup Setuju } \rightarrow 3 \\
\text { Kurang Setuju } \rightarrow 2 \\
\text { Tidak Setuju } \rightarrow 1\end{array}$} \\
\hline 2 & $\begin{array}{l}\text { Sampah rumah tangga yang dibiarkan menumpuk menimbulkan } \\
\text { dampak buruk bagi lingkungan. }\end{array}$ & \\
\hline 3 & Sampah organik dan anorganik harus dipilah. & \\
\hline 4 & Pengelolaan sampah organik menjadi kompos memberikan manfaat. & \\
\hline 5 & Pemakaian plastik sebaiknya dikurangi. & \\
\hline 6 & Sampah yang masih bisa dipakai sebaiknya dimanfaatkan kembali. & \\
\hline 7 & Pemilahan sampah rumah tangga mudah dilakukan. & \\
\hline 8 & Kang Pisman efektif dalam mengatasi masalah sampah. & \\
\hline 9 & $\begin{array}{l}\text { Pembayaran biaya retribusi pengelolaan sampah harus dilakukan } \\
\text { secara rutin. }\end{array}$ & \\
\hline
\end{tabular}

\section{HASIL DAN PEMBAHASAN}

\subsection{Efektivitas Program Kang Pisman}

Sebelum melakukan pengolahan data telah dilakukan uji validitas dan reliabilitas terhadap butir-butir variabel dalam kuesioner. Uji validitas dilakukan dengan menggunakan teknik korelasi product moment dari Pearson dengan rumus sebagai berikut [14]:

$$
r_{x y}=\frac{N \sum X Y\left(\sum X\right)\left(\sum Y\right)}{\sqrt{\left\{N \sum X^{2}-\left(\sum X\right)^{2}\right\}\left\{N \sum Y^{2}-\left(\sum Y\right)^{2}\right\}}}
$$

Dimana:

$\mathrm{r}_{\mathrm{Xy}} \quad=$ koefisien korelasi Pearson

$\Sigma \mathrm{XY}=$ jumlah hasil kali skor $\mathrm{X}$ dan $\mathrm{Y}$

$\Sigma \mathrm{X}=$ jumlah skor $\mathrm{X}$

$\Sigma \mathrm{Y} \quad=$ jumlah skor $\mathrm{Y}$

$\Sigma \mathrm{X}^{2} \quad=$ jumlah skor $\mathrm{X}$ yang dikuadratkan

$\Sigma \mathrm{Y}^{2} \quad=$ jumlah skor $\mathrm{Y}$ yang dikuadratkan

$\mathrm{N} \quad=$ jumlah responden

Sebagai contoh perhitungan uji validitas variabel motivasi:

$$
\begin{aligned}
& r x y=\frac{(98)(29.336)-(351)(8.174)}{\sqrt{(98)(1.283)-(351)^{2}} \sqrt{(98)(754.814)-(8.174)^{2}}} \\
& r x y=0,592
\end{aligned}
$$

Dengan persamaan uji validitas tersebut didaptkan nilai koefisien korelasi (r) dari variabel motivasi

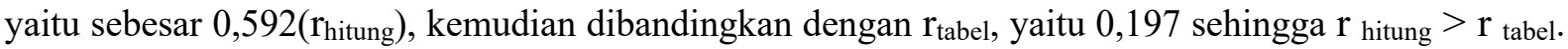
Hasil uji validitas variabel lain juga menunjukkan bahwa seluruh variabel bebas dan terikat dalam penelitian ini valid karena nilai signifikansi $<0,05$ dan nilai $r$ hitung $>r$ tabel. Setelah uji validitas, dilakukan juga uji reliabilitas guna mengetahui kestabilan dan konsistensi alat pengumpulan data. Uji reliabilitas dilakukan menggunakan Cronbach's Alpha dengan rumus sebagai berikut [15]: 


$$
\alpha=\left[\frac{k}{k-1}\right]\left[1-\frac{\sum S_{i}^{2}}{S_{x}{ }^{2}}\right]
$$

Dimana:

$\mathrm{k}=$ jumlah instrument pertanyaan

$\Sigma S i^{2}=$ jumlah varians dari tiap instrumen

$S x^{2}=$ varians dari keseluruhan instrumen

Uji reliabilitas yang menggunakan Cronbach's Alpha dengan 13 instrumen pertanyaan memperoleh nilai sebesar 0,775 ( $\left.\mathrm{r}_{\text {hitung }}\right)>0,197\left(\mathrm{r}_{\text {tabel }}\right)$ yang artinya variabel tersebut reliabel untuk digunakan.

Program Kang Pisman atau gerakan kurangi, pisahkan dan manfaatkan sampah, merupakan kolaborasi antara pemerintah, warga, swasta dan lainnya dalam membangun peradaban baru pengelolaan sampah yang lebih maju dan berkelanjutan. Penghitungan efektivitas program dilakukan dengan menjumlah semua skor pada variabel efektivitas yang disajikan dalam tabel frekuensi berikut ini:

Tabel 5. Motivasi mengikuti Program Kang Pisman

\begin{tabular}{lccc}
\hline Motivasi & Frekuensi & Persentase (\%) & Skor \\
\hline Termotivasi & 58 & 59,2 & 232 \\
\hline Cukup Termotivasi & 39 & 39,8 & 117 \\
\hline Kurang Termotivasi & 1 & 1,0 & 2 \\
\hline Tidak Termotivasi & 0 & 0 & 0 \\
\hline Total & $\mathbf{9 8}$ & $\mathbf{1 0 0}$ & $\mathbf{3 5 1}$ \\
\hline
\end{tabular}

Berdasarkan Tabel 5, dapat diketahui bahwa masyarakat lebih banyak yang termotivasi untuk mengikuti Program Kang Pisman yaitu sebanyakk 59,2\% dan hanya 1\% saja yang kurang termotivasi, sedangkan sisanya cukup termotivasi sebanyak 39,8\%. Motivasi ini bisa didapatkan hanya pada saat masyarakat mengerti betul tujuan yang hendak dicapai program tersebut. Guna menyebarluaskan program dan sosialisasi terhadap masyarakat diadakan penyuluhan baik tingkat kelurahan maupun tingkat yang lebih kecil seperti RW dan RT. Penyuluhan juga dilakukan secara door to door langsung menyasar rumah warga. Sejumlah spanduk yang juga digunakan sebagai media edukasi terpasang di beberapa lokasi. Program Kang Pisman juga dibantu dengan keikutsertaan LSM YPBB Bandung yang berlokasi di kelurahan tersebut. Kehadiran responden dalam penyuluhan program dapat dilihat dalam Tabel 6.

Tabel 6. Kehadiran dalam penyuluhan program

\begin{tabular}{lccc}
\hline Kehadiran dalam Penyuluhan & Jumlah & Persentase (\%) & Skor \\
\hline Ya, Responden Sendiri & 62 & 63,3 & 186 \\
\hline Ya, Salah Satu dari Anggota Keluarga & 21 & 21,4 & 42 \\
\hline Tidak Ada & 15 & 15,3 & 15 \\
\hline Total & $\mathbf{9 8}$ & $\mathbf{1 0 0}$ & $\mathbf{2 4 3}$ \\
\hline
\end{tabular}

Berdasarkan Tabel 6, lebih banyak responden yang menghadiri sendiri penyuluhan Program Kang Pisman yaitu $63,3 \%$ sedangkan sebanyak $21,4 \%$ dihadiri oleh salah satu angota keluarga dan sebanyak $15,3 \%$ yang tidak hadir dalam penyuluhan. Penyuluhan dalam skala kecil biasanya dilakukan bersamaan dengan kegiatan yang dilakukan warga, misalnya pertemuan PKK, pengajian dan arisan warga. Penyuluhan seperti ini biasanya lebih mengena dan di terima masyarakat karena disampaikan dengan mudah misalnya menggunakan bahasa dan konteks lokal oleh kader Program Kang Pisman yang juga merupakan warga setempat.

Selain dengan penyuluhan, promosi terhadap masyarakat juga dilakukan melalui berbagai media baik cetak maupun elektronik. Program Kang Pisman sendiri mempunyai website yang bisa diakses untuk 
mendapatkan informasi mengenai program tersebut dan beberapa poster yang bisa di unduh untuk berbagai keperluan. Halaman media sosial Kang Pisman juga turut aktif dalam menggalakkan program yang ramah lingkungan ini. Remaja dan anak-anak tidak luput menjadi sasaran dari program karena mereka adalah aset yang akan meneruskan program ini. Beberapa sekolah sudah menjadi mitra kegiatan yang berkelanjutan ini.

Tabel 7 menggambarkan tingkat pengetahuan responden tentang program Kang Pisman. Pengetahuan tersebut meliputi tiga fokus utama dari program itu sendiri, yaitu kurangi, pisahkan dan manfaatkan sampah. Sebanyak 73,5\% responden mampu menjelaskan program secara benar, sedangkan 14,3\% menjawab benar pada dua aktivitas bagian dari Kang Pisman, dan 10,2\% hanya menjawab benar pada salah satu kegiatan dan sisanya $2 \%$ menjawab salah atau mampu menjawab tapi terbalik.

Tabel 7. Pengetahuan tentang program

\begin{tabular}{lccc}
\hline Pengetahuan tentang Program & Jumlah & Persentase (\%) & Skor \\
\hline Menjawab Benar Semua & 72 & 73,5 & 288 \\
\hline Menjawab Dua Benar & 14 & 14,3 & 42 \\
\hline Menjawab Satu Benar & 10 & 10,2 & 20 \\
\hline Menjawab Salah Semua & 2 & 2 & 2 \\
\hline Total & $\mathbf{9 8}$ & $\mathbf{1 0 0}$ & $\mathbf{3 5 2}$ \\
\hline
\end{tabular}

Pengetahuan tentang kurangi sampah banyak dijawab responden dengan mengurangi plastik, karena memang beberapa sosialisasi tentang pelarangan plastik sekali pakai sudah demikian masif. Meskipun sebenarnya, pengurangan sampah tidak hanya plastik tetapi juga semua jenis barang yang berpotensi menjadi sampah. Hal ini sejalan dengan upaya pengurangan budaya konsumerisme masyarakat dan mendukung konsumsi yang berkelanjutan.

Tabel 8 merupakan gambaran responden dalam upaya pengurangan plastik atau sampah sekali pakai. Sebanyak $27,6 \%$ masyarakat sudah sering mengurangi penggunaan plastik dan sampah sekali pakai, sedangkan $44,9 \%$ cukup sering dan $27,6 \%$ jarang. Tidak ada responden yang menjawab tidak pernah, yang berarti meskipun belum rutin, masyarakat sudah mulai mencoba mengurangi penggunaan plastik dan bahan sekali pakai. Cara mengurangi plastik yang paling banyak dilakukan responden adalah dengan membawa botol minum, tempat makan dan juga kantong belanja sendiri. Sampah plastik harus dikurangi karena beresiko mencemari lingkungan dan membahayakan kesehatan, tidak seperti sampah organik yang bisa diolah kembali. Penggunaan barang sekali pakai mengalami peningkatan seiring dengan kebutuhan masyarakat akan kepraktisan dan kenyamanan. Padahal, salah satu tujuan Sustainable Development Goals salah satunya adalah secara substansial mengurangi produksi limbah melalui tindakan pencegahan, pengurangan, daur ulang dan penggunaan kembali.

Tabel 8. Pengurangan plastik dan sampah sekali pakai

\begin{tabular}{lccc}
\hline $\begin{array}{l}\text { Pengurangan Plastik dan } \\
\text { Sampah Sekali Pakai }\end{array}$ & Jumlah & $\begin{array}{c}\text { Persentase } \\
(\mathbf{\%})\end{array}$ & Skor \\
\hline Sering & 27 & 27,6 & 108 \\
\hline Cukup Sering & 44 & 44,9 & 132 \\
\hline Jarang & 27 & 27,6 & 54 \\
\hline Tidak Pernah & 0 & 0 & 0 \\
\hline Total & $\mathbf{9 8}$ & $\mathbf{1 0 0}$ & $\mathbf{2 9 4}$ \\
\hline
\end{tabular}

Langkah yang perlu dilakukan setelah melakukan pengurangan sampah adalah melakukan pemilahan terhadap sampah yang dihasilkan. Pemilahan sampah yang sederhana dilakukan masyarakat adalah memilah sampah basah, kering dan sampah residu. Sampah basah adalah sampah dari sisa konsumsi dari dapur, sering disebut dengan sampah organik. Sampah ini bisa dimanfaatkan kembali menjadi kompos dan biogas. Sampah kering adalah sampah yang masih bisa di manfaatkan kembali atau 
bahkan dijual untuk memperoleh pendapatan. Sampah yang tergolong sampah kering diantaranya botol kemasan dan kertas/kardus. Sisanya yang tidak temasuk keduanya adalah sampah residu, yang tidak bisa dimanfaatkan kembali dan harus berakhir di TPA. Pemilahan sampah bermanfaat mengurangi jumlah akhir sampah yang harus dibawa ke TPA apabila pemilahan sudah dilakukan semenjak dari sumber.

Tabel 9. Frekuensi Pemilahan Sampah Sejak dari Sumber

\begin{tabular}{lccc}
\hline Pemilahan Sampah & Jumlah & Persentase (\%) & Skor \\
\hline Sering & 41 & 41,8 & 164 \\
\hline Cukup Sering & 32 & 32,7 & 96 \\
\hline Jarang & 20 & 20,4 & 40 \\
\hline Tidak Pernah & 5 & 5,1 & 5 \\
\hline Total & $\mathbf{9 8}$ & $\mathbf{1 0 0}$ & $\mathbf{3 0 5}$ \\
\hline
\end{tabular}

Berdasarkan data dalam Tabel 9 responden menjawab sering melakukan pemilahan sampah sebanyak $41,8 \%$, cukup sering memilah sebanyak $32,7 \%$. Sedangkan $20,4 \%$ responden jarang melakukan pemilahan sampah dan sebanyak $5,1 \%$ tidak pernah melakukan pemilahan sampah di rumah. Biasanya warga sudah memisahkan sampah kering ditempat tersendiri, sedangkan sampah basah dibuatkan tempat terpisah misalkan menggunakan ember dan sampah residu disendirikan untuk diangkut petugas sampah. Di Kelurahan Sukaluyu beberapa petugas pengumpul sampah sudah menggunakan wadah terpilah untuk memisahkan sampah basah dari warga yang kemudian dibawa ke sarana pengolahan yang sudah disediakan.

Jika pola pengelolaan sampah masih menggunakan paradigma kumpul - angkut - buang maka semua sampah baik organik maupun anorganik tercampur menjadi satu dan semuanya berakhir di TPA. Jika TPA masih menggunakan sistem open dumping yaitu sampah hanya ditumpuk begitu saja maka sampah organik yang terurai tanpa oksigen akan menghasilkan gas rumah kaca $\left(\mathrm{CH}_{4}, \mathrm{CO}_{2}, \mathrm{NO}_{2}\right)$ yang berbahaya dan gugus amin yang menimbulkan bau busuk. Selain itu, timbulan air lindi (leachate) sebagai efek dekomposisi biologis dari sampah juga memiliki potensi besar dalam pencemaran badan air sekelilingnya, terutama air tanah dibawanya. Sampah yang tercampur begitu saja juga menurunkan kualitas daur ulang dari sampah anorganiknya.

Tabel 10. Pemanfaatan Kembali Sampah yang Masih Bisa Digunakan

\begin{tabular}{lccc}
\hline $\begin{array}{l}\text { Memanfaatkan Kembali Sampah } \\
\text { yang Masih Bisa Digunakan }\end{array}$ & Jumlah & $\begin{array}{c}\text { Persentase } \\
(\mathbf{\%})\end{array}$ & Skor \\
\hline Sering & 31 & 31,6 & 124 \\
\hline Cukup Sering & 36 & 36,7 & 108 \\
\hline Jarang & 27 & 27,6 & 54 \\
\hline Tidak Pernah & 4 & 4,1 & 4 \\
\hline Total & $\mathbf{9 8}$ & $\mathbf{1 0 0}$ & $\mathbf{2 9 0}$ \\
\hline
\end{tabular}

Setelah melakukan pengurangan dan pemilahan, beberapa sampah bisa dimanfaatkan menjadi barang yang dapat digunakan lagi. Dengan memperpanjang umur suatu barang dan menambah nilai guna, maka akan memperlama sampah tersebut berakhir ke TPA. Tabel 10 menyajikan data mengenai pemanfaatan kembali sampah yang masih bisa digunakan. Sebanyak $31,6 \%$ responden sering memanfaatkan kembali sampah, 36,7\% cukup sering, $27, \%$ jarang dan $4,1 \%$ tidak pernah melakukan hal tersebut.

Sampah organik bisa dimanfaatkan untuk biogas dan kompos, tetapi sarana pengolahannya berada di fasilitas komunal yang dikelola kelurahan atau RW setempat seperti mesin digester, tong komposter, bata terawang dan lain-lain. Meskipun ada juga beberapa warga yang membuat kompos sendiri dari rumah masing-masing. Sedangkan sampah yang dapat dimanfaatkan kembali oleh masyarakat secara 
pribadi biasanya sampah yang mempunyai nilai jual, termasuk dalam jenis sampah kering dan biasanya dapat di tabung ke bank sampah. Selain di tabung ke bank sampah, banyak warga yang memanfaatkan sampah anorganik ini untuk sedekah sampah, yaitu memberikan secara cuma-cuma kepada pemulung atau yang membutuhkan. Sampah juga dapat di gunakan kembali misalnya untuk pot bunga, kap lampu, dan bahan kerajinan lain. Sebagai contoh, ada beberapa warga yang memanfaatkan sisa kemasan sachet kopi untuk membuat barang-barang kebutuhan rumah tangga, seperti tikar, keranjang, tas belanja dan bahkan membuat rajutan dengan plastik kresek bekas.

Tabel 11. Jumlah Sampah yang Berakhir ke TPA

\begin{tabular}{lccc}
\hline $\begin{array}{l}\text { Jumlah Sampah yang } \\
\text { Berakhir ke TPA }\end{array}$ & Jumlah & $\begin{array}{c}\text { Persentase } \\
(\mathbf{\%})\end{array}$ & Skor \\
\hline Berkurang Banyak & 13 & 13,3 & 52 \\
\hline Berkurang Sedikit & 49 & 50.0 & 147 \\
\hline Tetap & 36 & 36,7 & 72 \\
\hline Bertambah & 0 & 0 & 0 \\
\hline Total & $\mathbf{9 8}$ & $\mathbf{1 0 0}$ & $\mathbf{2 7 1}$ \\
\hline
\end{tabular}

Tujuan utama Program Kang Pisman adalah mengurangi, memisahkan dan memanfaatkan sampah agar dapat mengurangi beban kerja TPA. Propinsi Jawa Barat memiliki riwayat bencana nasional longsornya TPA Leuwigajah di tahun 2005 yang menewaskan banyak jiwa dan membuat dua kampung disekitarnya tertimbun longsoran tanah. Longsoran tersebut diakibatkan karena TPA tersebut masih menggunakan sistem open dumping yakni di buang dan di tumpuk begitu saja, sehingga gunungan sampah yang tinggi itu goyah terkena hujan deras dan terpicu ledakan akibat konsentrasi gas metan. Kejadian tersebut menegaskan bahwa sampah bisa menjadi bom waktu yang akan membahayakan manusia itu sendiri. Menurut data pada Tabel 11, setelah adanya Program Kang Pisman sampah, 13,3\% responden menjawab sampah yang dihasilkan menjadi berkurang banyak, sedangkan sampah yang berkurang sedikit yaitu sebanyak $50 \%$ responden, sisanya sebanyak $36,7 \%$ menyatakan jumlah sampahnya tetap seperti sebelum ada program.

Setelah dijumlah keseluruhan skor jawaban responden terhadap variabel penyusun efektivitas, didapatkan bahwa skor total efektivitas adalah 2.106 yang artinya berada pada tingkatan cukup efektif. Klasifikasi efektivitas Program Kang Pisman di Kelurahan Sukaluyu disajikan dalam Tabel 12.

Tabel 12. Klasifikasi Efektivitas

\begin{tabular}{lcc}
\hline Klasifikasi Efektivitas & Jumlah & Persentase (\%) \\
\hline Efektif & 18 & 18,4 \\
\hline Cukup Efektif & 61 & 62,2 \\
\hline Kurang Efektif & 19 & 19,4 \\
\hline Tidak Efektif & 0 & 0 \\
\hline Total & $\mathbf{9 8}$ & $\mathbf{1 0 0}$ \\
\hline
\end{tabular}

Di Kelurahan Sukaluyu banyak warga masyarakat yang sudah melaksanakan pilah sampah dari rumah. Acara yang melibatkan warga masyarakat seperti rapat, arisan, senam dan kerja bakti juga sudah dianjurkan untuk menyajikan konsumsi tanpa kemasan sekali pakai. Pada awalnya itu terlihata repot, tetapi setelah beberapa kali mencoba ternyata hanya dibutuhkan keteraturan untuk menjadi kebiasaan sehingga lama-lama mudah dilakukan. Kesulitan yang sering dihadapi untuk memilah sampah ada di area komersil dan juga rumah yang di sewakan/kost. Letak strategis Kelurahan Sukaluyu yang dilalui jalan arteri primer yaitu Jl. Surapati membuat sektor komersil berkembang. Pengelolaan sampah pada sektor usaha ini masih dikelola oleh masing-masing pemilik usaha dengan sistem kumpul - angkut buang. Rumah kost/kontrakan yang sering berganti penghuni juga lebih sering menolak untuk memilah sampah yang dihasilkan. 


\subsection{Faktor-Faktor yang Mempengaruhi Efektivitas Program Kang Pisman}

Setelah mengetahui tingkat efektivitas Program Kang Pisman di Kelurahan Sukaluyu, maka perlu diketahui faktor yang dapat berpengaruh pada efektivitas program tersebut. Analisis regresi linear berganda dengan software IBM SPSS Statistics v25 dilakukan guna mengetahui pengaruh 6 variabel bebas terhadap variabel terikat yaitu efektivitas. Sebelum dilakukan regresi, data pada penelitian ini telah memenuhi beberapa asumsi, yaitu:

a. Normalitas. Uji normalitas menggunakan Normal P-P Plot. Plot data mendekati garis diagonal artinya variabel pengganggu (e) terdistribusi normal. Hasil uji normalitas ditampilkan pada Gambar 1.

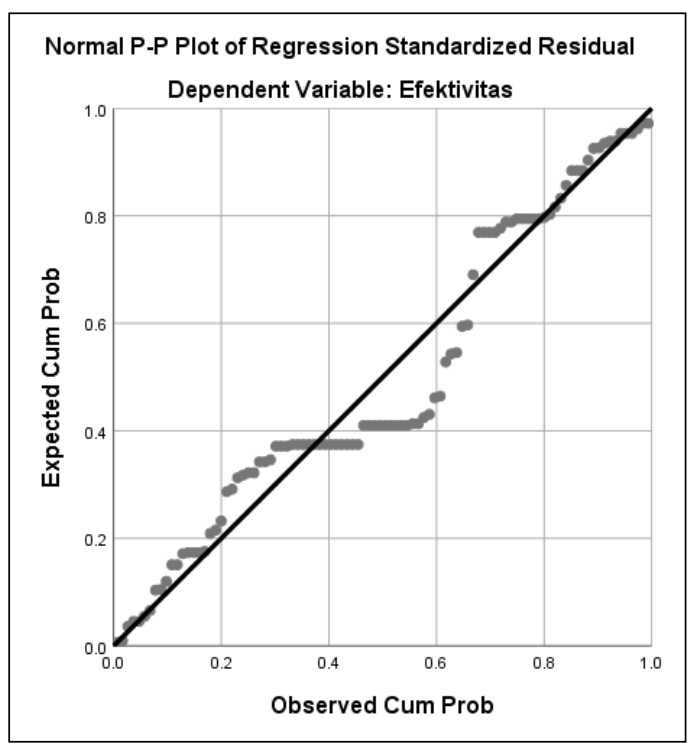

Gambar 1. Hasil Uji Normalitas

b. Heteroskedastisitas. Uji heteroskedastsitas dilakukan dengan melihat hasil scatterplots. Titik-titik data menyebar di atas dan di bawah atau di sekitar angka 0 , tidak hanya mengumpul di atas atau di bawah saja. Penyebaran titik-titik data tidak membentuk pola bergelombang, seperti terlihat pada Gambar 2.

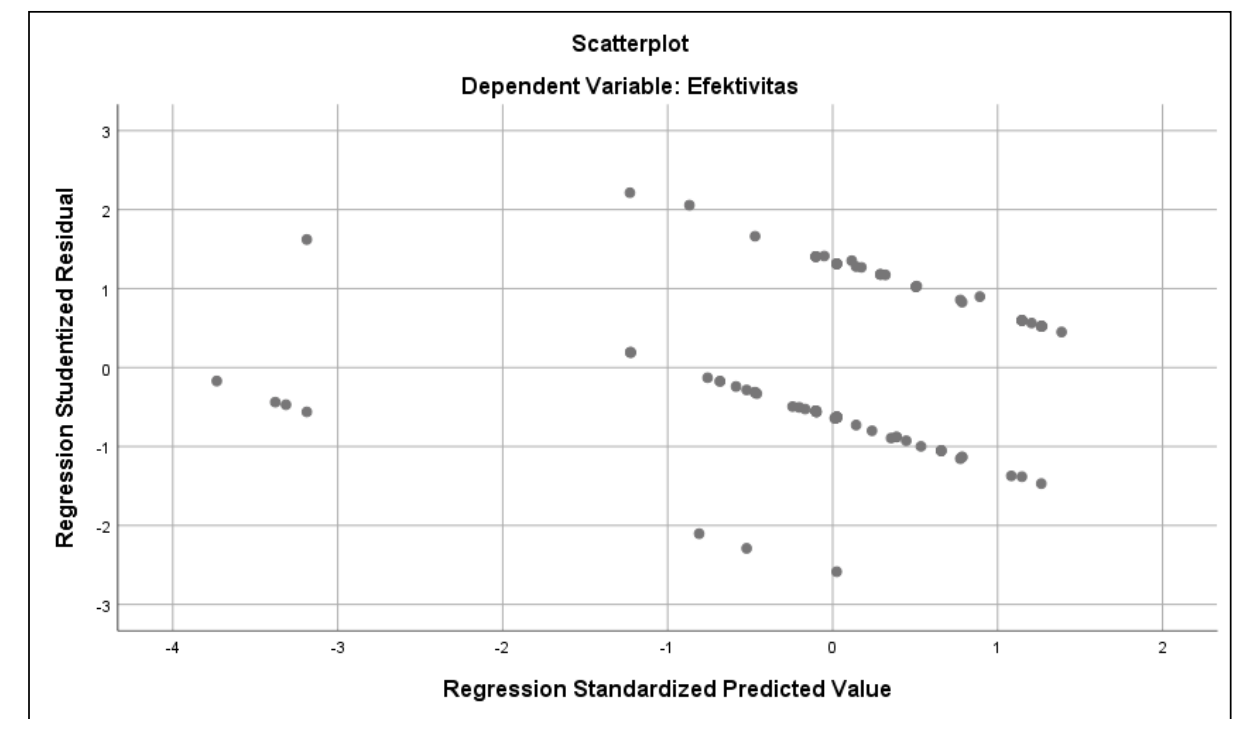

Gambar 2. Hasil Uji Heteroskedastisitas 
c. Tidak ada multikolinearitas sempurna antar variabel independen. Uji ini dilakukan dengan melihat nila statistik $\mathrm{VIF}<10$.

Analisis regresi yang digunakan dalam pengolahan data penelitian ini adalah metode enter yang artinya semua variabel bebas dimasukkan ke dalam persamaan baru kemudian di lihat nilai $\mathrm{R}^{2}$. Nilai $\mathrm{F}$ digunakan untuk melihat keseluruhan persamaannya dan nilai $t$ untuk masing-masing variabel bebas. Berdasarkan Tabel 13 variabel bebas (X) secara simultan berpengaruh terhadap variabel terikat (Y). Hal ini dapat dilihat nilai signifikansi $0,000<0,05$ dan nilai $F_{\text {hitung }}$ sebesar 6,667 $>\mathrm{F}_{\text {tabel }} 2.20$.

Tabel 13. Hasil Uji F

\begin{tabular}{lrrrrr}
\hline \multicolumn{1}{c}{ Model } & $\begin{array}{c}\text { Sum of } \\
\text { Squares }\end{array}$ & df & $\begin{array}{c}\text { Mean } \\
\text { Square }\end{array}$ & F & Sig. \\
\hline Regression & 22.504 & 6 & 3.751 & 6.677 & $.000^{\mathrm{b}}$ \\
\hline Residual & 51.120 & 91 & 0.562 & & \\
\hline Total & 73.624 & 97 & & & \\
\hline
\end{tabular}

Berdasarkan Tabel 14 dapat diketahui bahwa nilai $\mathrm{r}$ (koefisien korelasi) sebesar 0,553 yang berarti bahwa variabel bebas dan terikat dapat dikategorikan memiliki hubungan linear yang cukup [16]. Sedangkan nilai koefisien determinasi $\left(\mathrm{R}^{2}\right)$ sebesar 0,306 yang artinya variabel bebas $(\mathrm{X})$ secara simultan berpengaruh terhadap variabel terikat $(\mathrm{Y})$ sebesar 30,6 \% sedangkan sisanya dipengaruhi variabel lain. Nilai koefisien determinasi adalah dari $0-1$. Untuk penelitian yang cross section nilai ini dapat dikatakan cukup baik sehingga layak untuk dijadikan alat analisis dan estimasi [17].

Tabel 14. Model Summary

\begin{tabular}{rcrrr}
\hline Model & R & R Square & $\begin{array}{c}\text { Adjusted R } \\
\text { Square }\end{array}$ & $\begin{array}{c}\text { Std. Error } \\
\text { of the } \\
\text { Estimate }\end{array}$ \\
\hline 1 & $.553 \mathrm{a}$ & 0.306 & 0.260 & 0.74951 \\
\hline
\end{tabular}

Nilai standard error of the estimate pada Tabel 14 adalah 0,74951. Nilai tersebut apabila dibandingkan dengan $10 \%$ nilai predicted value dalam Tabel 15 maka didapatkan $(0,74951>$ 0,39091 ). Artinya model tersebut valid untuk membuat prediksi pada variabel bebas dan persamaan yang dihasilkan bisa menjadi alat prediksi dan estimasi. Persamaan yang dihasilkan adalah:

$$
\begin{array}{r}
\mathrm{Y}=-1,208+0,150 \mathrm{X}_{1}+0,257 \mathrm{X}_{2}+0,021 \mathrm{X}_{3}+0,045 \mathrm{X}_{4}+0,715 \mathrm{X}_{5}-0,042 \mathrm{X}_{6} \\
(\mathrm{t}=1,161) \quad(\mathrm{t}=2,876)(\mathrm{t}=0,145)(\mathrm{t}=0,406) \quad(\mathrm{t}=4,454)(\mathrm{t}=-0,360) \quad(\mathrm{F}=6,667)
\end{array}
$$

Tabel 15. Residual Statistics

\begin{tabular}{lccccc}
\hline & Minimum & Maximum & Mean & Std. Deviation & N \\
\hline Predicted Value & 2.1108 & 4.5775 & 3.9091 & .48166 & 98 \\
\hline Residual & -1.92085 & 1.57985 & .00000 & .72596 & 98 \\
\hline Std. Predicted Value & -3.734 & 1.388 & .000 & 1.000 & 98 \\
\hline Std. Residual & -2.563 & 2.108 & .000 & .969 & 98 \\
\hline
\end{tabular}

Tabel 16 menunjukkan bahwa variabel yang berpengaruh signifikan terhadap efektivitas Program Kang Pisman adalah variabel kemudahan menjalankan program dan persepsi masyarakat. Hal ini dapat dilihat dari nilai signifikansi dan nilai thitung variabel tersebut yang lebih besar dari nila tabel. Nilai $\mathrm{t}(91 ; 0,025)$ dari tabel adalah 1,98638. Nilai thitung dari variabel kemudahan program adalah 2,876 dan nilai thitung dari variabel persepsi adalah 4,454 . Kedua variabel tersebut mempunyai pengaruh hubungan 
positif dengan efektivitas. Semakin mudah program tersebut di jalankan akan semakin efektif. Persepsi responden yang semakin baik juga meningkatkan efektivitas program.

Tabel 16. Koefisien $(\alpha=0,05)$

\begin{tabular}{lccccc}
\hline \multirow{2}{*}{ Model } & \multicolumn{2}{c}{$\begin{array}{c}\text { Unstandardized } \\
\text { Coefficients }\end{array}$} & $\begin{array}{c}\text { Standardized } \\
\text { Coefficients }\end{array}$ & & \\
\cline { 2 - 5 } & $\mathbf{B}$ & Std. Error & Beta & t & Sig. \\
\hline (Constant) & -1.208 & 0.883 & & -1.369 & 0.174 \\
\hline Komitmen Pemerintah & 0.150 & 0.129 & 0.154 & 1.161 & 0.249 \\
\hline Kemudahan Program & 0.257 & 0.089 & 0.262 & 2.876 & 0.005 \\
\hline Kinerja Petugas & 0.021 & 0.145 & 0.021 & 0.145 & 0.885 \\
\hline Sarana Prasarana & 0.045 & 0.111 & 0.046 & 0.406 & 0.686 \\
\hline Persepsi terhadap Program & 0.715 & 0.160 & 0.393 & 4.454 & 0.000 \\
\hline Peran LSM & -0.042 & 0.117 & -0.043 & -0.360 & 0.720 \\
\hline
\end{tabular}

Persepsi berhubungan kuat dengan partisipasi masyarakat dalam pengelolaan sampah rumah tangga [18]. Persepsi responden terhadap program merupakan faktor yang berpengaruh paling signifikan terhadap efektivitas program. Persepsi merupakan salah satu aspek psikologis yang penting bagi manusia dalam merespon berbagai aspek dan gejala di sekitarnya. Program Kang Pisman bertolak pada partisipasi warga dalam mengelola sampah rumah tangga. Masyarakat adalah aktor penting demi berjalannya program tersebut. Persepsi masyarakat terhadap program akan mempengaruhi partisipasi dalam menjalankan program tersebut. Partisipasi dari berbagai pihak merupakan kunci keberhasilan suatu kegiatan ataupun program yang meliputi pengambilan keputusan, pelaksanaan, penilaian dan pemanfaatan hasil [19]. Semakin baik persepsi masyarakat terhadap pengelolaan sampah rumah tangga maka Program Kang Pisman akan semakin efektif. Gambar 3 menyajikan data tentang persepsi responden terhadap sampah, pengelolaan sampah dan terhadap program. Sebanyak 95\% responden mempunyai persepsi yang baik terhadap hal tersebut, sedangkan sisanya 5\% mempunya persepsi cukup baik.

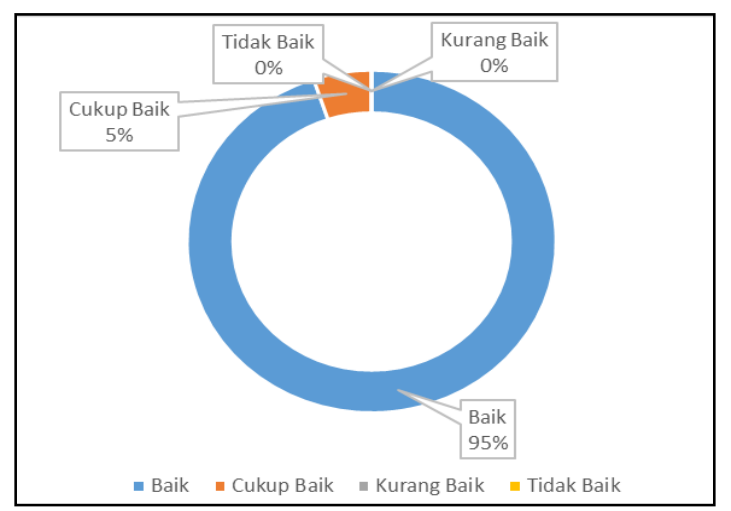

Gambar 3. Persepsi Responden terhadap Sampah, Pengelolaan Sampah dan Program

Faktor kedua yang berpengaruh signifikan terhadap efektivitas Program Kang Pisman adalah kemudahan dalam menjalankan program. Faktor kenyamanan dan kemudahan merupakan faktor penting dalam perilaku daur ulang masyarakat [20], [21]. Tidak dipungkiri untuk menjalankan suatu hal yang baru, diperlukan proses pembelajaran dan pembiasaan. Semakin mudah program tersebut untuk dipelajari maka semakin berpengaruh positif terhadap keefektifan program. Beberapa responden 
yang menyatakan program ini mudah, pada awalnya telah mengalami beberapa kesulitan. Kesulitan tersebut bisa diatasi dengan melakukan pembiasaan, misalnya memilah dengan dua jeni sampah dahulu, baru kemudian tiga jenis. Tingkat kemudahan menjalankan program juga bisa ditunjang dengan ide-ide kreatif seperti aplikasi di gawai, memberi label pada tempat sampah terpilah semenarik mungkin, sosialisasi lagu Kang Pisman dan lomba kampung Kang Pisman. Pada Gambar 4 ditampilkan tanggapan responden terhadap kemudaan pengelolaan sampah dengan Program Kang Pisman.

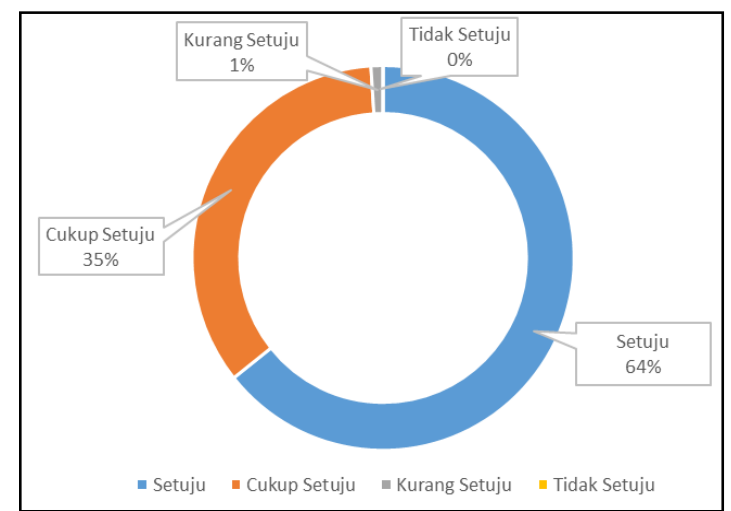

Gambar 4. Respon terhadap Kemudahan Program.

Gambar 4 menunjukkan bahwa Program Kang Pisman mudah dijalankan oleh 64\% responden. Sebanyak 35\% menyatakan program cukup mudah dan $1 \%$ menyatakan cukup sulit. Tidak ada repsonden yang menyatakan bahwa Program Kang Pisman sulit untuk dilakukan.

Dua faktor yang berpengaruh signifikan terhadap efektivitas Program Kang Pisman, yaitu persepsi masyarakat dan kemudahan dalam menjalankan program. Artinya, implementasi program tidak cukup hanya mengandalkan ketepatan program itu saja, tetapi harus memperhatikan juga masyarakat yang menjadi sasaran atau tujuan program.

\section{KESIMPULAN}

Berdasarkan olah data yang telah dilakukan terhadap beberapa variabel efektivitas, maka Program Kang Pisman yang sudah berjalan beberapa tahun terakhir cukup efektif untuk dijalankan guna mengurangi jumlah sampah yang di buang ke TPA. Pengelolaan sampah yang melibatkan masyarakat sebagai aktor utama merupakan keputusan yang tepat dalam mengantisipasi peningkatan volume sampah yang terus bertambah seiring peningkatan jumlah penduduk. Peran aktif masyarakat atau individu dapat dimulai dengan melakukan pengurangan sampah, pemilahan dan pemanfaatan kembali.

Faktor yang berpengaruh secara signifikan terhadap efektivitas Program Kang Pisman adalah faktor persepsi masyarakat terhadap program dan kemudahan dalam menjalankan program tersebut. Agar program ini bisa berjalan lebih efektif baik di Kelurahan Sukaluyu maupun di kelurahan lain, maka persepsi masyarakat harus dibangun mulai dari anggapan bahwa sampah yang merupakan sisa aktivitas manusia adalah tanggung jawab bersama, termasuk pemerintah dan masyarakat itu sendiri. Diskusi tentang pengelolaan sampah perlu diperbanyak dalam kegiatan keseharian masyarakat agar persepsi masyarakat semakin baik. Selain itu Program Kang Pisman harus di buat lebih mudah untuk dijalankan misalnya, dengan ide kreatif membuat aplikasi pilah sampah di gawai, permainan pilah sampah, memilah dua jenis sampah dahulu baru kemudian tiga jenis, dan memberi label pada tempat sampah dengan desain yang menarik. 


\section{DAFTAR PUSTAKA}

[1] Vassanadumrongdee, S., Kittipongvises, S. (2018). "Factors Influencing Source Separation Intention and Willingness to Pay for Improving Waste Management in Bangkok, Thailand." Sustainable Environment Research 28(2):90-99.

[2] PD Kebersihan Bandung. (2017). Rata-rata Produksi Sampah di Kota Bandung berdasarkan Sumber. Retrieved 23 Januari $2020 \mathrm{http} / /$ data.bandung.go.id/dataset/rata-rata-produksi-sampahberdasarkan-sumber-sampah-di-kota-bandung.

[3] Suyanto, Edy, Endriatmo, S., Sumardjo, Hartisari, H. (2015). "Model Kebijakan Pengelolaan Sampah Berbasis Partisipasi ‘Green Community’ Mendukung Kota Hijau.” Mimbar 31(1):143-52.

[4] Bappenas. (2017). Terjemahan Tujuan \& Target Global Sustainable Development Goals (SDGs). Jakarta.

[5] Zaman, Atiq, U., Lehmann, S. (2011). "Urban Growth and Waste Management Optimization toward 'Zero Waste City." City, Culture and Society 2:177-97.

[6] Setiawan, Pratiwi, R. (2020). "Factors Determining the Public Receptivity Regarding Waste Sorting: A Case Study in Surabaya City, Indonesia." Sustainable Environment Research 30(1):1.

[7] Nizar, M., Munir, E. (2017). "Manajemen Pengelolaan Sampah Kota Berdasarkan Konsep Zero Waste: Studi Literatur." Serambi Engineering 1(2).

[8] Connett, P. (2016). "Waste Management and Sustainability." Materi Kuliah Umum Sekolah Ilmu Lingkungan Universitas Indonesia \& Aliansi Zero Waste Indonesia.

[9] Patton, M, Q.. (2009). Metode Evaluasi Kualitatif. Yogyakarta: Pustaka Pelajar.

[10] Weiss, C, H. (1972). "Evaluation Research: Methods of Assessing Program Effectiveness." Social Forces 54(1).

[11] Osborne, D., Gaebler, T. (1993). Reinventing Government: The Five Strategies for Reinventing Government.

[12] Shabbir, C, G., Dennis, A, R. (1983). Decentralization and Develoment: Policy Implementation in Developing Countries. Beverly Hills: Sage Publication, Inc.

[13] Sinambela, L, P. (2014). Metode Penelitian Kuantitatif. Yogyakarta: Graha Ilmu.

[14] Notoatmodjo, S. (2002). Metode Penelitian Kesehatan. Jakarta: Rineka Cipta.

[15] Azwar, S. (2000). Reliabilitas Dan Validitas. Yogyakarta: Pustaka Pelajar.

[16] Siregar, S. (2013). Metode Penelitian Kuantitatif. Jakarta: Prenamedia Group.

[17] Gani, I., Siti, A. (2015). Alat Analisis Data: Aplikasi Statistik Untuk Penelitian Bidang Ekonomi Dan Sosial. Yogyakarta: Penerbit ANDI.

[18] Aditya, N., Surjono, H, S. (2018). "Persepsi Dan Partisipasi Masyarakat Terhadap Pengelolaan Sampah Rumah Tanga Melalui Bank Sampah Di Jakarta Selatan." Jurnal Pengelolaan Sumberdaya Alam Dan Lingkungan 8(1):7-14.

[19] Sumardjo. (2009). Modul Kuliah Teknologi Partisipatif Pengembangan Masyarakat. Bogor: Institut Pertanian Bogor.

[20] Bernstad, A. (2014). "Household Food Waste Separation Behavior and the Importance of Convenience." Waste Management 34(7):1317-23.

[21] Knickmeyer, D. (2020). "Social Factors Influencing Household Waste Separation: A Literature Review on Good Practices to Improve the Recycling Performance of Urban Areas." Journal of Cleaner Production 245:118605. 